\title{
Thomas Crone*
}

\section{The semantic change of the word $\min$ 民 in texts of the Eastern Zhou Period (771-221 BC)}

DOI 10.1515/asia-2015-0066

\begin{abstract}
This paper is a follow-up to a previous study whose results suggest that the term min 民 in texts of the Western Zhou Period (ca. 1045-771 BC) primarily refers to subjected lineages and rulers outside of the ancestral homeland of the Zhou kings. The assumption derived from this, namely, that min might have served to distinguish populations of peripheral territories that were supposedly formally subjected to the royal house from those directly controlled by the Zhou kings, will be further examined in this article with regard to later texts of the Eastern Zhou Period. As the first two sections of this article reveal, in texts such as the Zuozhuan and the Guoyu, min continues to be used in a comparable way as it frequently addresses lineages of the dafu 大夫 rank, which in every single “country” (guo 國) could be similarly considered as subordinated “external” (wai 外) entities separated from the central ruling house. In relation to the phenomenon that in texts of the fourth and third centuries $\mathrm{BC}$ the semantic content of the word min appears to have shifted to addressing lower population strata, I conclude by arguing that this new usage of min to refer to "the common people" was born out of the political and social changes that occurred during the early Warring States Period and should not easily be projected onto earlier documents as it might lead to crucial misunderstandings in regard to the basic intentions and reasoning of these texts.
\end{abstract}

Keywords: $\min$ 民, ren 人, Zhou Period, social change, the people

\section{Introduction}

As I have argued in a previous study, the popular interpretation of the word min 民 as "the common people" in texts of the Western Zhou Period (ca. 1045-771 BC) ought to be questioned. ${ }^{1}$ Instead, the word's usage in inscriptions of

1 Crone 2014.

*Corresponding author: Thomas Crone, Institute of Oriental and Asian Studies/University of Bonn, Jagdweg 39, Bonn 53115, Germany. E-mail: crone.thomas@gmail.com 
excavated bronze ritual vessels and the traditionally received texts ascribed to this period suggests that min primarily referred to those parts of the entire population of the Zhou Kingdom that lived outside of the ancestral homeland of the Zhou people in present-day Shaanxi. They were first subjected to Zhou rule after King Wen claimed the receipt of the Heavenly Mandate (tianming 天命) and the successful military campaigns by his son King Wu. Following the hypothesis of Li Feng according to which terms such as bang 邦, guo 國, bo 伯 and hou 侯 are verbal expressions of a conceptual "bifurcation" of the Zhou Kingdom into a geopolitical center and periphery, ${ }^{2}$ I have come to the conclusion that the word min should also be understood within this framework. Accordingly, the expression min refers to the ruling lineages of the regional states of the Zhou Kingdom, who have been argued to have administratively and militarily represented autonomous political entities that were nominally subjected to the royal dynasty. ${ }^{3}$

In the same paper I proceeded to argue that the latently antagonistic relationship between the min and the Zhou kings, which is expressed in many passages of Western Zhou texts, should also be viewed in such a light. Even though the min had formally accepted the Heavenly Mandate and the rule of the Zhou Kings, their powerful position and geographical distance meant that controlling them required particular attention and was crucial to the stability of the Zhou Kingdom. Therefore, passages of the five gao 誥 (“pronouncement”) chapters of the Zhoushu 周書 that preach a cautious handling of the min should not be understood as an expression of altruistic concern about the general wellbeing of "the common people", but rather as a reflection of the realistic threat that the regional states' lineages represented to the Kings of Zhou. ${ }^{4}$

In this article, I seek to extend the investigation of the word min to texts of the subsequent Eastern Zhou Period (771-221 BC). My aim is to demonstrate that while passages of texts compiled during the early Warring States Period (475-221 BC), such as the Zuozhuan and Guoyu, still use min in a fundamentally similar way

2 Li 2006a: 110-116; 2008: 43-49. It should be noted that it was not Li Feng who first noted the "bifurcated" separation of the Zhou Kingdom into a geopolitical center and periphery. See, for example, the discussions found in Yoshimoto 2001 and Matsui 2001 respectively. For Li Feng's criticism of their approach, see Li 2008: 49 fn. 13.

3 Li 2006a: 115. There has been very little research with regard to the question of how the government of the regional states differed to that of the royal domain. However, the fact that the allocation and ownership of land appears to have been managed in distinct ways clearly supports the view that both territories were handled differently. See Lau 1999, whose study sharply distinguishes between the "enoffenment" (Belehnung) of "borderland rulers" (Grenzlandfürsten) and the allocation of "official territory" (Amtsland).

4 Crone 2014: 45-46. 
compared to texts of the Western Zhou Period, the semantic content of the term appears to have changed in later sources of the fourth and third century BC.

The evidence for this hypothesis is provided in three steps. The first part of this paper questions the interpretation of "the common people" for min in parts of the Zuozhuan and Guoyu by showing that it referred to the ruling houses of the dafu 大夫 rank within the single countries (guo 國) of the Zhou Kingdom. At the same time this section also casts doubts on the alternative interpretation of $\mathrm{min}$ as "alien clans", which has been put forward by Robert H. Gassmann in relation to Eastern Zhou texts, ${ }^{5}$ since the usage of the word min turns out to also not reflect upon the genealogical relationship of the particular group of individuals to their superior ruler. Therefore, despite the fact that my own understanding of the word min is undeniably indebted to Gassmann's intriguing approach to relate it to an “external” (wai 外) population group, I ultimately reject his interpretation.

The second part continues to explore the conceptual framework of the expression min in these sources by a comparative discussion of the complementary term ren 人, arguing that latter should be understood as designating servants and soldiers who were directly subjected to a particular ruler and thereby understood as representatives of the country's central political domain constituted by the ruling house. The term $\mathrm{min}$, on the other hand, appears to have been used to refer to those parts of the country's population that instead or in addition to a direct involvement in internal affairs of the ruling house, belonged to other subordinated lineages and were thereby bound by a different set of duties and interests. As the relationship between these lineages and the particular ruling house of the country resembles that of the King's of Zhou to the rulers of the regional states, I suggest that this usage of min could still be considered as designating geopolitically "peripheral” entities.

Then, in the last section, a final comparison of these findings with texts of the fourth and third centuries $\mathrm{BC}$ demonstrates that the word min underwent a semantic change in the course of the social changes and political reforms of the fifth and fourth centuries BC, as its conceptual framework can be shown to have clearly shifted to addressing lower and politically passive population strata.

\section{Min in the Guoyu and the Zuozhuan}

In the Zuozhuan, the first example of min referring to a dafu can be found in the anecdotes on the seizure of power and the murdering of the gong Huan of Wei 衛

5 For his latest discussion on this issue, see Gassmann 2006: 287-320. 
桓公 by his younger brother Zhouyu 州吁 in the fourth year of the gong Yin von $\mathrm{Lu}$ 魯隱公 (719 BC). According to the depiction of the Zuozhuan, Zhouyu attempted to gain recognition of his usurpation by the hou of the other countries in order to be able to "unite" (he 和) his $\min$. $^{6}$ He therefore provoked an attack against the country of Zheng to bring the rulers of the countries Song 宋, Chen 陳 and Cai 蔡 onto his side, as they were also enemies of Zheng. In the following section of the Zuozhuan, Zhouyu's behavior is criticized by a dafu of the country $\mathrm{Lu}$, who warns his ruler that Zhouyu's strategy will only lead to further complications. ${ }^{7}$ Only a few lines later the dafu's prophecy comes true: Zhouyu himself becomes the victim of a conspiracy and his reign ends, having lasted not even one year. What is interesting in regard to the semantic value of the word min is that this hitherto rather obscure group of individuals now starts to make a clear appearance:

州吁未能和其民。厚問定君於石子, 石子曰: “王軦為可。” “何以得唓?” 曰: “陳桓公 方有寵於王, 陳衛方睦。若朝陳使請, 必可得也。” 厚從州吁如陳, 石碏使告于陳曰: “衛 國褊小, 老夫老矣, 無能為也。此二人者, 實弑寡君, 敢即圖之。”陳人執之, 而請落于 衛。九月, 衛人使右宰醜泣殺州吁于兴, 石碏使其宰獳羊肩, 泣殺石厚于陳。

Zhouyu still couldn't unite his min. Shi Hou asked [his father] Shi Que how the rule [of Zhouyu] could be consolidated. Shi Que said: "By being received in a royal autumn audience.” Hou asked: "How does he [Zhouyu] obtain such?” Shi Que answered: “The ruler of Chen is a favorite of the King. The relations between Chen and Wei are good. An attempt by Chen to send for a royal invitation should be crowned with success." Hou followed Zhouyu to Chen. Shi Que sent his messenger to tell Chen: "Wei is small and I am an old and incapable man. These two [Hou and Zhouyu] are the actual murderers of my lord. If you dare, then make a scheme [to arrest them]!” The ren of Chen ${ }^{8}$ arrested both and asked to turn them over to Wei for their execution. In the ninth month the ren of Wei send the right superintendent Chou to arrange the killing of Zhouyu in $\mathrm{Pu}$ [a region of the country of Wei] and Shi Que sent his superintendent Nou Yangjian to kill Shi Hou in Chen. (Zuozhuan, "Zhuan": Yin 4.3, p. 36)

I will save myself the trouble of discussing the subsequent junzi 君子 commentary, which celebrates Shi Que's execution of his own son as "great righteousness annihilates [close] kinship” (da yi mie qin 大義滅親). More important with

6 See Zuozhuan, “Zhuan”: Yin 4.3, p. 36: 及衛州吁立, 將脩先君之怨於鄭, 而求寵於諸侯, 以和 其民. After Wei Zhouyu had mounted the throne, he wanted to intensify the hostility between his ancestors and the country of Zheng in order to be favored by the other hou and to unite his min. 7 See Zuozhuan, “Zhuan”: Yin 4.3, p.36: 臣聞以德和民, 不聞以亂。以亂, 猶治絲而棼之也. I have heard that the min can be united by acts of goodwill (de) but not by unrest (luan). [To unite them] by unrest is like tangling up silk threads.

8 I have deliberately chosen to not translate the word ren in this passage. See part two for a detailed explanation. 
regard to our topic is that the only manifestation of the introductory phrase "Zhouyu still couldn't unite his min" appears to be in the complot conducted by Shi Que, as neither in this passage nor elsewhere are other actions against Zhouyu mentioned. However, if one continues to understand min as "the common people" or as "alien clans", then it needs to be explained why the first sentence is followed by a depiction of Shi Que's actions, since he was certainly not a "commoner" and neither did he possess another clan surname than the ruling house of Wei. ${ }^{9}$

A very similar example can be found in relation to the death of the gong Xiang of Qi 齊襄公 in the eighth year of the gong Zhuang of Lu 魯莊公 (686 BC), who was a victim of a rebellion by Lian Cheng 連稱 and Guan Zhifu 管至父. At the end of the military turmoil the reader is told that the gong Xiang had originally been warned by his dafu Bao Shuya 鮑叔牙 that "if a lord carelessly sends his min, unrest will be caused” (jun shi min man, luan jiang zuo yi 君使民 慢, 亂將作矣). ${ }^{10}$ At first glance this warning does not appear very specific, but by paying closer attention to the phrase zuo luan 作亂 “to cause unrest”, one can see that Bao Shuya's warning turns out to be a prophecy of the rebellion of Lian Cheng and Guan Zhifu. Both directly following his warning and also in the previous sections, it is only the uprising of both men that is repeatedly described with the phrase zuo luan (three times). In relation to the first usage of the phrase, one also finds a hint of what Bao Shuya meant by the "careless" handling of the min, since it turns out that the gong Xiang had originally "sent” (shi 使) Lian Cheng and Guan Zhifu to administer a certain territory and had promised them that “when the pumpkins are ripe” (ji gua 及瓜) he would send their replacement. But after he had not kept his promise and had even rejected their plea for him to do so, Lian Cheng and Guan Zhifu started to "plan to cause unrest" (mou zuo luan 謀作亂). ${ }^{11}$ This not only semantically coincides with the Bao Shuya's warning, but also uses the exact same words, such as "send" (shi) and "to cause unrest” (zuo luan). It therefore appears obvious that Bao Shuya's commentary

9 According to the Shiben, Shi Que was not only a dafu of the country of Wei, but also shared the clan surname Ji 姬 with the ruling house of Wei. See Shiben, pp. 158 f., 206.

10 See Zuozhuan, “Zhuan”: Zhuang 8.3, p.177.

11 Zuozhuan, “Zhuan”: Zhuang 8.3, p.176: 初, 襄公使連稱、管至父戌葵丘。瓜時而往, 及瓜而 代。往戍一歲卒, 瓜時而公弗為發代。或為請代, 公弗許。故此二人怒, 因公孫無知謀作亂。 Originally the gong Xiang had sent Lian Cheng and Guang Zhifu to guard the hills of Kui. [They were told to] set off after the seed of the pumpkins and wait for the replacement until the pumpkins would have turned ripe. After one year had passed and the pumpkins were sown again, the gong still hadn't sent their replacement. They repeatedly asked for the replacement, but the gong didn't give his permission. Therefore, these two ren became angry and were induced by the plans of Gongsun Wuzhi to cause unrest. 
should be understood as a wise counsel that would have prevented the rebellion against the ruler of Qi. Thus the word min is understood as denoting persons, such as Lian Cheng and Guan Zhifu - although neither of them are likely to have belonged to "the common people", but were relatively high-ranking and powerful rulers of the country of Qi. ${ }^{12}$

Several pieces of further evidence can be found in the anecdotes related to the political rise of the lineage of Jisun 季孫 in the country of Lu. Since the beginning of the sixth century $\mathrm{BC}$, the Jisun had increasingly turned into direct competitors of their superior ruler. Together with the other lineages of the Shusun 叔孫 and Mengsun 孟孫, they belonged to the descendants of the gong Huan of Lu 魯桓公 (711-694 BC) and were therefore known as the "three Huan" (san huan 三桓). Together with the ruling house of Lu, they all shared the clan surname Ji and continued to dominate the politics of $\mathrm{Lu}$ for centuries. As recounted in the Zuozhuan, the internal struggle between the three Huan and the rulers of $\mathrm{Lu}$ acquired a new dimension when the gong Zhao of $\mathrm{Lu}$ 魯昭公 (? - 510 BC) conducted a military campaign against the Jisun. Unfortunately, the other lineages of the Shusun and Mengsun came to the Jisun's assistance and defeated the troops of the gong Zhao, forcing him to flee to the neighboring country of Qi, from where he was unable to return until after his death.

It goes without saying that such an incident could not simply be ignored by the hou rulers of the other countries. During their meeting two years later, a possible solution to this conflict became a central matter of discussion, the result of which was in favor of the Jisun:

\section{宋、衛皆利納公, 固請之。范獻子取貨於季孫, 謂司城子梁與北宮貞子曰: “季孫未知其 罪，而君伐之。請囚，請亡，於是乎不獲。君又弗克，而自出也。夫豈無備而能出君乎？ 季氏之復，天救之也。休公徒之怒，而啟叔孫氏之心。不然，豈其伐人而說甲執冰以游？ 叔孫氏懼禍之濫，而自同於季氏：天之道也。魯君守齊，三年而無成。季氏甚得其民，淮 夷與之。有十年之備, 有齊楚之援, 有天之贊, 有民之助, 有堅守之心, 有列國之權, 而 弗敢宣也! 事君如在國, 故鞅以為難。二子皆圖國者也, 而欲納魯君, 鞅之願也。請從二 子以圍魯, 無成, 死之。”二子懼, 皆辭, 乃辭小國, 而以難復。}

For the countries Song and Wei, a return of the gong [Zhao of Lu] was advantageous and they therefore pleaded for it. But Fan Xianzi was bribed by the Jisun and told the head of construction Le Qi and Beigong Xi: "Although [the patriarch] of the Jisun was not conscious of his guilt, the ruler [Zhao of Lu] campaigned against him. He [the patriarch of the

12 There is no record of the genealogical origin of Lian Cheng in the Shiben. However, with regard to his alliance with Guan Zhifu, it appears likely that he was a dafu as the Shiben tells us that Guan Zhifu was a dafu of the country of Qi and a descendant of the King Mu of Zhou 周穆 王, thus possessing the clan surname Ji. See Shiben, p. 192. The gong of Qi had the clan surname Jiang 姜. 
Jisun] pleaded for imprisonment or exile, but he didn't receive any of it. Then the ruler [Zhao of Lu] didn't even manage to defeat [the Jisun] and decided to leave his country. How could the ruler have been exiled without any arrangements [on behalf of the Jisun]? The revolt of the Jisun happened with the help of Heaven. He calmed the anger of the gong's foot soldiers and opened the heart of the Shusun. If not, how could the ren have rested themselves by taking off their armory and holding their quivers in their hands during the attack $?^{13}$ The Shusun feared that they would become the next victim and joined the Jisun: This is the way of Heaven. The ruler of Lu is keeping watch from Qi and has not had any success in the last three years. The Jisun obtained [strong control over] his min, and the Huayi allowed them. For ten years they have been making arrangements, they have been reinforced by the countries of Qi and Chu, possess the favor of Heaven and the help of the min, a resolute heart and the actual power of an entire country - but they never dared to [officially] announce it! They are serving their ruler as if he were still in the country and this is why I think it will be tough. But you two act in the interest of your countries, and to bring the ruler of Lu back on his throne is also my wish. Allow me to join you and lay siege on Lu. If we fail, we shall die!” The two were afraid and declined their wish. They then declined the wishes of the small countries and replied that it was too tough. (Zuozhuan, “Zhuan”: Zhao 27.4, pp. 1486-1487)

Fan Xianzi skillfully interprets the intervention of the Shusun in favor of the Jisun as a heavenly-controlled twist of fate. But the min also appear to be an important ally of the Jisun, as they are mentioned repeatedly in relation to the Jisun's military success. While the immediate context of this passage does not allow a detailed identification of the particular persons related, the depiction of the fight between the Jisun and the ruler of Lu two years earlier quite clearly reveals that the min mentioned here are nobody other than the Shusun themselves. During the course of the events, the order of which closely follows the description given by Fan Xianzi, no group other than the Shusun acted in support of the Jisun. In addition, the dafu Zijiazi 子家子 is recorded as having warned the ruler of Lu immediately before their revolt that the min might start to "give birth to their own heart" as a result of his political carelessness. ${ }^{14}$ The expression used, sheng xin 生心, is strikingly close to the phrase qi xin 啟心 “"to open the heart") used by Fan Xianzi in his speech describing the Shusun's change of allegiance. ${ }^{15}$ This warning therefore appears to represent another

13 As I argue below, ren refers here to the foot soldiers of the gong of Zhao mentioned a sentence earlier.

14 Zuozhuan, “Zhuan”: Zhao 25.6, p.1464.

15 Qi xin and sheng xin appear to belong to an entire group of expressions found in the Zuozhuan and other works of the Zhou Period that use "heart" (xin) as a metaphor for political loyalty and allegiance. A semantically related example would be the expression er xin 二心 ("double-heartedness"), sometimes also simply referred to as er 武 (“two"), which together with its antonym yi xin 一心 ("one-heartedness") refers to the states of betrayal and loyalty respectively. See also Luo 1986, juan 1, shang ce, pp.19/122, entries no. two and one, as well as juan 10, p.134, entry no. 
prophecy announcing the Shusun's (and possibly also Jisun's) breach of loyalty and the subsequent political demise of the ruler of $\mathrm{Lu}$.

Further passages suggesting that the dafu themselves were commonly regarded as representatives of the min emerge during the immediate aftermath of the successful revolt of the "three Huan". As a result of the hopeless situation of the ruler Zhao during his exile in the country of Qi, the rest of the dafu who had initially still stood loyal to him, such as the above-mentioned Zijiazi, now slowly appear to be turning away from him. In the end, Heaven himself appears to take the fate of the ruler of Zhao into his own hands:

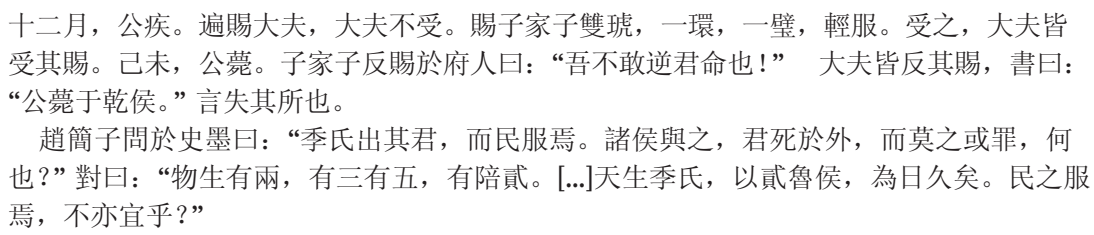

In the twelfth month, the gong became sick. He gave presents to all of his dafu, but the dafu didn't accept [them]. He gave two tiger-shaped jade stones to Zijiazi, a circlet and a disk and some fine clothing. He accepted and the other dafu all accepted their presents. On day jiwei (56) the gong died. Zijiazi returned his presents to the royal treasurer and said: "I do not dare to receive my lord's mandate." ${ }^{\prime 6}$ The dafu all returned their presents and recorded in their annals: "The gong died in Qianhou." This meant that he had lost his territory.

Zhao Jianzi asked the scribe Mo: "The Jisun have exiled their lord and the min submitted to them. The other hou accept this, the ruler of Lu dies outside his country and no one accuses them [the Jisun]! How can this be?" The scribe answered: "Of some things there are two of the same kind, of some three or five. They are partners and assistants. [...] Heaven has given birth to the Jisun to assist the ruler of Lu a long time ago. That the min subject to them, why shouldn’t it be? (Zuozhuan, “Zhuan”: Zhao 32.4, p. 1519-1520)

\footnotetext{
eleven. Direct proof that both phrases are used in a similar sense in the Zuozhuan is found in one passage of the 28th year of the gong Zhuang. See Zuozhuan, “Zhuan”: Zhuang 28.2, p. 240: 疆埸 無主, 則啟戎心。戎之生心，民慢其政，國之患也。If the borders are without ruler, the Rong will open their heart (qi rong xin). If the Rong give birth to their heart (rong zhi sheng xin), the min will neglect the political orders and become a concern for the country.

16 I translate the phrase ni ming 逆命 here as “to receive the mandate”, since the verb ni 逆, in addition to its other meaning of "to resist" can also be used in the sense of "to receive/ welcome" (antonym of "to see off”, song 送). In other passages of the Zuozhuan and other texts of the Zhou Period, such as the “Lü xing” 呂刑, the expression ni ming is used in this sense of "to receive/accept a mandate". See the second entry of $n i$ and the first entry of ni ming in Luo 1986 , juan 10, pp. 824, 828 . With regard to the return of the presents, this translation is clearly superior to the alternative of "to resist/reject the mandate".
} 
It is obvious that the dialogue between Zhao Jianzi, a dafu from the country of Jin, and the scribe Mo refers to the actions of Zijiazi and the remaining allies of the gong Zhao of Lu. The return of their presents can be regarded as a gesture symbolizing the revocation of their loyalty to the ruling house of Lu. Zijiazi's statement, together with the sentence recorded in the annals of the dafu, further supports this hypothesis. The min are therefore represented here by the remaining dafu and by Zijiazi, who after the death of the ruler of $\mathrm{Lu}$, start to reconcile themselves with the new political situation. It should be emphasized that the particular group of people referred to here by the word min is distinct from the group in the passage discussed above. The persons called min here accept their new ruler, while the min in the passage above had already become allies of the Jisun in their revolt against the gong of Lu. What unites both parties is that they belong to the same semantic category: They are both groups led by powerful dafu lineages, which are formally inferior to the gong of $\mathrm{Lu}$.

Seen in the context of this phenomenon, alternative translations such as "the common people" or "alien clans" fail because they assume that there is a third population part that is unrelated to the several lineages and dafu discussed above. It is entirely incomprehensible how such a third party would be able to help to start a revolt and then become subject to it. Instead, the reading of min that I have presented above not only helps to illuminate the specific passages it is used in, but can also make sense of this alleged paradox.

Such a usage of the word min may not be restricted to the Zuozhuan alone, but may have been common to other texts of the early Warring States Period. This is suggested by a passage from the Guoyu, which clearly identifies the dafu as members of the category of min:

伯宗朝, 以喜歸, 其妻曰: “子貌有喜, 何也?” 曰: “吾言于朝, 諸大夫皆謂我智似陽子。” 對曰: “陽子華而不實, 主言而無謀, 是以難及其身。子何喜焉?”伯宗曰: “吾飲諸大夫 酒, 而與之語, 爾試聽之。” 曰: “諾。” 既飲, 其妻曰: “諸大夫莫子若也。然而民不能戴 其上久矣, 難必及子乎! 盍函索士憖庇州犁焉?”

得畢陽。及欒弗忌之難, 諸大夫害伯宗, 將謀而殺之。畢陽實送州犁于荊。

Bo Zong returned home happily from a court audience. His wife asked him: "Why do you look so happy?" [He] said: "The other dafu have praised my speech during the court audience and said I am as wise as Yang Chufu.” [His wife] answered: "Yang Chufu was extravagant and not substantial, he emphasized speech and had no advice and plans, which brought him many difficulties. Why are you happy about this?” Bo Zong said: "I will invite the dafu to drink with me and I will converse with them. You try and listen to us." His wife said yes. When they had finished drinking his wife said: "The other dafu can indeed not be compared to you. But the min will not carry someone above them for too long, hardship will befall you! Why don't you go and find someone who will hide [your son] Zhouli?" 
[Bo Zong] found Bi Yang. When the hardship of Luan Fuji befell him, and the other dafu harmed him and planned his murder, Bi Yang brought Zhouli to Jing. (Guoyu 11.14, pp. 384-385)

Here it is once more the dafu who hide themselves behind the word min. Their clan surname also appears to be largely irrelevant. According to the Zuozhuan, the deaths of Luan Fuji and Bo Zong were mainly caused by the dafu lineages of the "three Xi" (san xi 三郤). ${ }^{17}$ All of them (including Bo Zong and Luan Fuji) shared the clan surname Ji, as well as of the superior ruling house of the country Jin. ${ }^{18}$ This passage therefore disproves again the interpretations of the word $\mathrm{min}$ discussed above.

\section{From $\min$ to ren}

It has long been noted that texts of the Eastern Zhou Period frequently use the term ren as a complementary counterpart to the word $\min ^{19}$ In this section, I will take advantage of this phenomenon by arguing that a further comparison of both words reveals that they reflect a conceptual framework comparable to the "bifurcated" structure of the Western Zhou Kingdom. While their sociopolitical background slightly differs from the original model as they address different populations within one country and not within the entire kingdom, they still follow the traditional principle of distinguishing between internal and external entities.

I commence by discussing two records of the pair of ren and min found in bronze inscriptions of the Spring and Autumn Period (770-476 BC). I start here because these inscriptions may represent the earliest form of textual evidence that we currently possess of the complimentary usage of both terms. ${ }^{20}$ Of course, there are also traditionally received sources that may provide evidence that a similar pair already existed during the Western Zhou Period, but I do not include them in

17 Zuozhuan, “Zhuan”: Cheng 15.5, p. 876: 晉三卻害伯宗, 譖而殺之, 及樂弗忌。 The three Xi of Jin harmed Bo Zong, they slandered and killed him. Le Fuji was caught up [in the killing].

18 Shiben, pp. 217-219.

19 Ames \& Hall 1987: 138-156; Gassmann 2006: 287-320; Song 2003: 21-40; Zhao 1976: 1-59. Unlike his predecessors, Gassmann's study does not restrict itself to the Lunyu, but includes other sources, such as the Zuozhuan or the Guoyu.

20 Li Xueqin's dating of the first vessel, the Qi hou hu 齊侯壼, is early Spring and Autumn Period. See Li 2006b: 1-6. The second inscription, which belonged to the so-called Qi hou bo 齊 侯鎛, was probably cast during the middle Spring and Autumn Period, since its donor appears to have been a grandchild of the above-mentioned dafu Bao Shuya. 
the discussion as the precise dating of these sources is very controversial. ${ }^{21}$ In addition to their advantage of representing historically verifiable sources, a close examination of the relevant passages of both bronze inscriptions also turns out to be surprisingly helpful with regard to the understanding of the two terms:

\section{齊侯既濟（躋）洹子孟姜喪。其人民都邑堇（謹）骞（要）（舞）無用從（縱）爾大樂。}

The hou of Qi arrived at the funeral of Huanzi's Senior [daughter] of the clan surname Jiang. His ren and min, his capital and settlements had to exactly follow his demands to not indulge in loud music. (JC: 9729, based on the translation of Li 2006b)

侯氏易（賜）之邑二百又九十又九邑。與郘之民人都畗（鄙）。

The hou presented him with 299 settlements. He gave him the min and ren, the capitals and peripheral regions of Xun. (JC: 271)

Note that ren and min do not appear in a strict order, a phenomenon that generally indicates that they have not yet evolved into a new compound word and should be read separately. ${ }^{22}$ With this in mind, the parallel enumeration of both terms together with capitals ( $d u$ 都), settlements ( $y i$ 邑) and peripheral regions ( $b i$ 鄙) turns into a crucial piece of evidence, as these inscriptions suggest that ren and min were apparently understood as entities separated along the conceptual distinction between a geopolitical center and a periphery.

That this simple phrase is far from a meaningless coincidence, but rather deeply reflects the elemental features of the socio-political structure of the early Zhou Kingdom, is further revealed by paying closely attention to a certain usage of the word ren in other texts of the Spring and Autumn and Warring States Period, such as the Zuozhuan quoted above and its original subject, the Spring and Autumn Annals. What I seek to address here is the recently-debated issue that the meaning of compound words based upon the name of a country and the word ren, such as weiren 衛人, jinren 育人 or churen 楚人, cannot be fully understood by simply using the ordinary interpretation of ren as "humans" or "men". This is because only certain parts and not the entire population of these countries appear to be addressed by these compounds. Van Auken, who has dedicated an entire study to the meaning of these words, demonstrates that in

21 Coordinated phrases such as ren min or min ren, suggesting a semantic relationship between the two terms, can, for example, also be found in the "Daya" 大雅 section of the Book of Odes, which is often believed to date to the Western Zhou Period. See Mao Shi zhengyi, juan 18-1, p. 555; juan 18-2, p. 559; juan 18-5, p. 577. According to the Mao-Commentary these odes date to the reigns of the late Western Zhou King Li and King You.

22 Shengli Feng 1998: 222-224. 
some of the records of the Spring and Autumn Annals such words are listed together with the names of other rulers: ${ }^{23}$

宋公、陳侯、蔡人、衛人伐鄭。

The gong of Song, the hou of Chen, the ren of Cai, the ren of Wei attack Zheng. (Zuozhuan, “Jing”: Yin 4.4, p. 34)

宋公、曹伯、衛人、制人伐齊。

The gong of Song, the bo of Cao, the ren of Wei, the ren of Zhu attack Qi. (Zuozhuan, "Jing”: Xi 18.1, p. 376)

季孫宿會晉侯、鄭伯、齊人、宋人、衛人、制人于邢丘。

Jisun had a gathering with the hou of Jin, the bo of Zheng, the ren of Qi, the ren of Song, the ren of Wei, the ren of Zhu in Xingqiu. (Zuozhuan, "Jing”: Xiang 8.4, p. 955)

Van Auken continues to reveal more intriguing evidence that even in particular anecdotes of the Zuozhuan expressions in the style of "ren of country X" are likewise listed together with the names of rulers of other countries. She also points out that sometimes those who are referred to as "ren of country X" in the records of the Spring and Autumn Annals turn out to be certain rulers in the anecdotes of the Zuozhuan. ${ }^{24}$ She therefore argues that the term "ren of country $\mathrm{X}$ " most probably refers to the single person of the particular ruler himself. ${ }^{25}$ Without denying the plausibility of her conclusion, her claim that "ren of country X" must refer to a certain individual and not to a group of people, rests on the assumption that the names of the rulers listed actually only refer to single persons. However, this premise is revealed as very questionable when one considers that many actions that are performed by those rulers, such as "to attack" ( $f a$ 伐) or even "to siege" (wei 圍), appear to have been of a collective nature, and required the participation of other personnel or troops. As van Auken herself realizes, movements of entire armies are sometimes "ascribed" to an "individual leader". ${ }^{26}$

I would therefore like to take her analysis in a different direction and argue that these passages show that subjects, who could be high-ranking officials but also troops or other servants of a country's ruler, were subsumed into the expression "ren of country X". As they owed direct allegiance to a particular ruling house, they functioned as extensions of the individual ruler himself, who,

23 Van Auken 2011: 307-320.

24 Van Auken 2011: 562.

25 Van Auken 2011: 561.

26 Van Auken 2011: 563. 
as it has been pointed out repeatedly, verbally marked himself as guaren 寡人 (“the solitary ren”) or yu yi ren 余一人 (“I, the single ren”).

This interpretation is also in harmony with certain usages of ren some of the passages of the Zuozhuan quoted above. One can, for example, return to the anecdote portraying the execution of Zhouyu, which mentions him being arrested by the "ren of Chen". Given the fact that his execution was conducted and arranged by “superintendents" (zai 宰) from the country of Wei, it appears likely that ren also referred to troops or other servants of the ruler of Chen. While this passage certainly also leaves room for alternative interpretations, another even more appealing example can be found in the speech of Fan Xianzi that describes the uprising of the three Huan lineages that was quoted above. In his attempt to persuade the rulers of the other countries not to attack the Jisun, he also refers to a certain group of ren whose surrender is described as "taking of their armory and holding their quivers in their hands” (shi jia zhi bing 釋甲執冰). I repeat this part here in order to facilitate the discussion that follows:

季氏之復, 天救之也。休公徒之怒, 而啟叔孫氏之心。不然, 豈其伐人而說甲執冰以游?

The revolt of the Jisun occurred with the help of Heaven. He calmed the anger of the gong's foot soldiers and opened the heart of the Shusun. If not so, how could the ren have rested themselves by taking off their armory and holding their quivers in their hands during the attack? (Zuozhuan, “Zhuan”: Zhao 27.4, p. 1486)

As with many of the passages quoted above in relation to $\mathrm{min}$, one needs to examine the relevant passage that portrays the actual event of surrender in order to understand which group of people are addressed as ren here. In examining the course of events recorded two years earlier, one finds a more detailed depiction of the surrender that is phrased in a strikingly similar way. This is presumed by a scene in which the “supervisor of horses" (sima 司馬) of the Shusun, Zong Li 鬷戻, is described as gathering and addressing his zhong 眾 27 after the patriarch of the Jisun had been arrested by the gong Zhao of Lu:

27 Zhong is another term that appears to be closely related to the socio-political structure of the early Zhou Period. A detailed discussion of its meaning would certainly exceed the scope of this paper, especially as the first usages of the term can be traced back to the Shang Period. See Keightley 2012: 50-62. Judging from the immediate context, it appears likely that zhong were representatives of Zong Li's $\min$ (other subjected lineages). There appears to be a general connection between both terms, which can be deduced from the fact that a lack of support on behalf of the $\min$ for their superior ruler is often described as wu zhong 無眾 ("to-be-withoutzhong”) in passages of the Zuozhuan. See Zuozhuan, “Zhuan”: Zhuang 27.5, p. 236; Zuozhuan, Xi 13.4, p. 344. See also Gassmann 2006: 355-363. 
“若之何? ”莫對。又曰: “我, 家臣也, 不敢知國。凡有季氏與無, 於我孰利? 皆曰: “無 季氏, 是無叔孫氏也。”鬷戻曰: “然則救諸! ”帥徒以往, 陷西北隅以入。公徒釋甲執冰 而踞, 遂逐之。

"What shall we do?" No one answered. [Zong Li] spoke again: "We are the servants of the [Shusun] family (jia), we don't dare to think of our country (guo). The existence or the end of the Jisun, what is beneficial to us?" All answered: "The end of the Jisun is the end of the Shusun.” Zong Li said: “Then we shall rescue them!” He took his foot soldiers and invaded from the northwest. The foot soldiers of the gong [Zhao of Lu] took off their armory and kneeled down, their quivers in their hands. Zong Li chased them away. (Zuozhuan, "Zhuan": Zhao 25.6, p.1464)

Returning to Fan Xianzi's speech, it should now be obvious that the persons he refers to as ren are indeed the gong's foot soldiers (gongtu 公徒) mentioned in his speech only a sentence earlier. However, while this question has been solved, this particular usage of the noun ren appears to be in conflict with how it is most commonly interpreted here. It cannot be read as a pronoun in the sense of "others", or simply as a word for "human" or "humans", as the translation, "how could the humans/others have rested themselves", does not allow the reader to realize that it actually refers to the previously mentioned foot soldiers. The third interpretation that I introduced above provides a convenient way out of this dilemma. Used in this sense, ren could be understood here as referring to servants of the ruling house of $\mathrm{Lu}$, to which the foot soldiers certainly belonged.

Comparing these results to the initially examined term $\mathrm{min}$, it is striking that the designated dafu and their lineages appear not to simply function as representatives and direct servants of the ruling house, but as autonomous and distinct entities. While they are all nominally subordinated to the particular ruling house of their country, they quite obviously possessed their own political ambitions. This is not only demonstrated by their notoriously rebellious behavior in the quoted anecdotes of part one, but ultimately also by the above-quoted speech of Zong Li itself, as he clearly distinguishes between his duties, which result from him being a "servant of his house" (jiachen 家臣) and his external duties in relation to the country (guo) his house belonged to.

As this relationship between the ruling house and the min obviously shares fundamental similarities with that of the King's of Zhou and their regional rulers, I suggest that the usage of min (and ren) in the above-quoted passages of the Zuozhuan and Guoyu still follows the basic principle of a conceptual distinction between a geopolitical center and a periphery found in earlier texts of the Western Zhou Period. This, of course, also allows the possibility that the particular population group referred to by min was of poor and humble status, while 
ren could also be used to refer to persons of high rank such as a dafu. ${ }^{28}$ However, the above-quoted passages make it clear that the concept related to both terms cannot have been solely based upon a simple vertical hierarchy. Instead, the semantic difference involved in calling a group of people ren or min appears to have lied within their relationship to the superior ruling house. Referred to as min, the emphasis is put on their status as an autonomous political entity which had to be treated with respect and whose loyalty had to be cautiously obtained. Referred to as ren, the semantic focus lies on the fact that their relationship to his superior ruler was instead or additionally defined by a form of personal employment, forcing them to act as a political representative of the particular ruler and country.

\section{The usage of $\min$ in texts of the fourth and third centuries $B C$}

The established view of political and social developments in ancient China during the fifth and fourth centuries $\mathrm{BC}$, as it is generally described in the secondary research literature, is that the complex aristocratic hierarchies of the early Zhou kingdom gradually vanished as a result of political reforms and power struggles among the different ruling houses and lineages. ${ }^{29}$ Instead, large territorial states emerged, which were governed by a single ruler and his apparatus of officials. In contrast to the previous system, they could be appointed and dismissed from their positions by the central government according to their job performance. Although there had already been similar attempts to centralize power during the Spring and Autumn Period, ${ }^{30}$ there is a broad consensus among scholars that the crucial shift from the old "law of lineages” (zongfa 宗 法) to the new system of “elevating the worthy" (shang xian 尚賢) or "ranks of [military] merit” (jungong juezhi 軍功爵制) did not occur before the late Spring and Autumn and early Warring States Periods. ${ }^{31}$ From the perspective of the state ruler, the advantage of this new form of government obviously lay in the

28 Compare Van Auken 2011: 562, who points out that some passages of the Zuozhuan show that ren could also designate dafus.

29 Among others, see Lewis 1999: 597-619; Hsu 1965: 37-52, 78-106; Zhu 1990/2004: 559-579.

30 E.g. the reorganization of state power in Qi and Jin during the seventh century BC. See Hsu 1999: 553-560.

31 Lewis 1999: 598; Hsu 1965: 93; Zhu 1990/2004: 561. 
significant consolidation of power and control that he gained over his territory. While the rulers of the early Zhou Period relied heavily on the loyalty and consent of the inferior lineages in order to govern their lands, the new state rulers of the Warring States Period could exercise control over all their states' territories and populations equally well through their officials. As Mark Lewis writes:

The correlate of the concentration of power in the ruler and the central court was the extension of state control into the rural hinterlands. This extension was based on the development of a new political role, that of the dependent official who was the creature of the ruler. The ability to appoint officials, dispatch them to remote cities, maintain control over them at distance, and remove them when necessary was essential to the creation of a territorial state. ${ }^{32}$

Lewis' depiction of these new kinds of officials as "creatures" of their superior should not distract us from the fact that the acquisition of these new governmental positions was nevertheless of high interest for many candidates of lower aristocratic origin. As Pines has pointed out recently, the appointed officials of the new territorial states could possess considerable rights and power and their positions were therefore often highly prestigious. ${ }^{33}$ However, Lewis is correct in pointing out that the political reforms led to a new level of dependence and subjection among the population of these new territorial states, which in turn led to the intensification of social stratification. In particular, the lineages of the dafu discussed above, struggled notoriously to redefine their place within the new system. An archaeological survey by Falkenhausen, which investigated the tombs of such ruling houses, suggests that for many of them these political changes eventually led to their social and financial decline. ${ }^{34}$ While the new meritocratic policies introduced by the central rulers certainly promoted both downward and upward mobility, the gradual disappearance of the previously mentioned horizontal hierarchy between different lineages eventually strengthened the vertical differences between those ruling from "above" (shang 上) and those being ruled "below" (xia 下).

Since the term min that has been analyzed in this paper was apparently closely related to the socio-political power structure of the early Zhou kingdom, it is only natural to assume that its semantic content was affected by these changes that occurred in the fifth and fourth centuries $\mathrm{BC}$, especially given that

32 Lewis 1999: 603.

33 See e. g. Pines 2009, "To Serve or Not to Serve": 136-162. I am indebted to Christian Schwermann for drawing my attention to this issue.

34 Falkenhausen 2006: 370-399. 
the word itself can be found in later texts and continued to be used after the founding of the Chinese empire in $221 \mathrm{BC}$. An initial piece of evidence can be found in a new attitude that is displayed towards the min in texts from the Warring States Period. Unlike the Zuozhuan or documents from the Spring and Autumn or Westen Zhou Periods discussed above, many texts written after the fifth century $\mathrm{BC}$ frequently associate the min with the intellectual deficit of (ethical) stupidity. ${ }^{35}$ This phenomenon raises increasing questions about the interpretation of $\mathrm{min}$ established above, since regarding high-ranking ruling houses of other subordinated lineages as stubborn and foolish would not only have been simply untrue in many cases, but could also have led to serious offenses and irritations. It therefore appears very unrealistic to assume that a similar part of the population is being referred to in one of the excavated Guodian texts, which is dated to at least $300 \mathrm{BC}$ and claims that, "the min can be made to follow [the principles of good government], they cannot be made to understand them." (min ke shi dao zhi, bu ke shi zhi zhi 民可复（使）道之，不 可复 (使) 智 (知) 之). ${ }^{36}$ Here the interpretation of “the common people” is more convincing, especially as the association of min with stupidity appears to become strengthened with the progress of social and political change during the Warring States Period, and in later imperial texts becomes a fundamental feature of the conceptual understanding of the term itself. ${ }^{37}$

Further evidence for a semantic change of the word min in texts of the middle and late Warring States Period can also be found in the fact that it is now often used as a close synonym for the term baixing 百姓 (“the hundred clans”). The text "Zi yi” 緇衣, which also belongs to the Guodian manuscripts, and can therefore be reliably dated to a time period before the year $300 \mathrm{BC}$, fortunately provides such an example:

子曰: “上好息 (仁)，則下之為息（仁）也争先。古（故）倀（長）民者，章志 以即 (昭) 百青 (姓), 則民至 (致) 行貢 (己) 以㢢 (悅) 上。《寺 (詩)》員 (云): “有直 (德) 行, 四方恐 (順) 之。”

35 See Schwermann 2011: 155-163, who discusses the issue of "stupidity" in ancient Chinese texts in great detail.

36 See strip no. 21 of the bamboo text “Zun de yi” 尊德義 in Guodian, p.56. For the transcription quoted here, see Guodian, p.174. An almost identical sentence can also be found in the Lunyu, where it is ascribed to Confucius. See Lunyu 8.9, p. 299.

37 The most exemplary case of such thinking can be found in the chapter "Da zheng xia" 大政 下 of the Xinshu 新書, where words such as ming 暝 (“darkness”) or mang 盲 (“blindness”) are treated as etymological relatives of the word min. See Schwermann 2011: 159-160. Similar explanations for the meaning of $\mathrm{min}$ are repeated in other texts of the Han Dynasty, such as the Chunqiu fanlu or Zheng Xuan's commentary to the chapter “Lü xing” 呂刑 of the Book of Documents. See Chunqiu fanlu, juan 10, pian 35, p. 286 and Liji zhengyi, juan 55, p.1647. 
The Master said: "If those above love benevolence, those below will compete for benevolence. Thus those who supervise the min must illuminate their will to the baixing, and the $\min$ will do all they can do to please those above. The Odes say: 'Being of virtuous ${ }^{38}$ conduct, the four quarters will follow him."” (Guodian, p. 129) ${ }^{39}$

Another even earlier example may be found in the Mozi, if one accepts the dating of the chapter "Against offensive war" (fei gong 非攻) to the fifth or fourth centuries BC, as is suggested by the secondary research literature: ${ }^{40}$

今師徒唯冉興起, 冬行恐寒, 夏行恐暑。此不可以冬夏為者也。春則廢民耕稼樹藝, 秋則 廢民穫斂。今唯冊廢一時, 則百姓飢寒凍餒而死者, 不可勝數。

If today soldiers are called to war, one is afraid of the cold during winter and one is afraid of the heat during summer. This is why one cannot go to war during winter and summer. During spring, however, one ruins the min's plowing, sowing and planting. During autumn, however, one ruins the min's harvest and collecting. If one ruins only one season, then the number of baixing who die from hunger and cold will be immeasurable. (Mozi 5.18 , p. 130)

The Mengzi provides a similar example, which is traditionally assumed to have been written during the third century $\mathrm{BC}:{ }^{41}$

\section{今王鼓樂於此，百姓聞王鐘鼓之聲，管篇之音，舉欣欣然有喜色而相告曰: “吾王庶幾無 疾病與? 何以能鼓樂也? ”今王田獵於此, 百姓聞王車馬之音, 見羽暆之美, 舉欣欣然有 喜色而相告曰“吾王庶幾無疾病與？何以能田獵也？”此無他，與民同樂也。今王與百姓同 樂, 則王矣。}

If Your Majesty today will play drums and music at this place, the baixing will hear the sounds of Your Majesty's bells, drums, mouth organs and flutes and will joyfully spring up and ask one another: "Has the illness of our King healed? How else could he play drums and music?" If Your Majesty today will hunt at this place, the baixing will hear the noise of the chariots and horses, they will see the beauty of the flags and will joyfully spring up and ask one another: "Has the illness of our King healed? How else could he go hunting?" This would be nothing but [Your Majesty] sharing his joy with the min. If Your Majesty would share his joy with the baixing today, he would become a [true] King! (Mengzi 1B.1, p. 105)

38 I choose to translate the word de 德 as “virtuous" here, as judging by the context of the quoted passage, it was apparently understood in this sense by the author(s) of the "Zi yi". This does not of course imply that such an interpretation of de respects the way it was originally used in the Odes.

39 Note that the Guodian "Zi Yi" is a manuscript version of the "Zi Yi" chapter as found in the received text of the $L i J i$ 禮記, which also contains a fundamental similar passage.

40 See Fraser 2014 for a detailed account on the contemporary state of research regarding the time of origin of the different parts of the received version of the Mozi.

41 Compare also Brooks \& Brooks 2002, who argue that the chosen passage should be in fact regarded as historically authentic and dated to the late fourth century BC. 
Finally, an example taking from the Han Feizi will be quoted, which also probably dates to the third century BC:

楚厲王有警鼓, 以百姓為戒。飲酒醉, 過而擊之也, 民大驚, 使人止之。曰: “吾醉而與 左右戲, 過擊之也。”民皆罷。居數月, 有警, 擊鼓而民不赴, 乃更令明號而民信之。

The King Li of Chu had an alarm drum to warn the baixing. Once when he was drunk, he made the mistake of beating it. The min were deeply terrified and [the King] sent his men (ren) to stop them. He said: "I was drunk and wanted to play a joke with my servants, so I wrongfully beat the drum." The min went home. Several months later, there was a warning, the drum was beaten but the min didn't follow. So the King once more ordered a clear signal and the min trusted it. (Han Feizi 11.32, p. 287)

The semantic coincidence of the terms min and baixing, which is apparently very common in texts of the Warring States Period, is revealing as both expressions had originally denoted very different populations categories in earlier periods. ${ }^{42}$ Two conclusions can be drawn from this parallel development. Firstly, the semantic change of both words was probably caused by the social and political changes of the fifth and fourth centuries $\mathrm{BC}$, as no evidence for a possible synonymous usage can be found in sources that can be dated with certainty to the Spring and Autumn or the Western Zhou Periods. Secondly, in texts of the later Zhou Period, both words appear to be semantically linked to a stereotypical account of representatives of the general population of the newly-founded territorial states. This has already been suggested with regard to the expression baixing. ${ }^{43}$ This interpretation appears reasonable in relation to min, not only because they were often regarded as "stupid" as we saw, but also because the

42 There have been different suggestions in relation to the interpretation of baixing, also written as baisheng 百生, which has been further linked to the expression duosheng 多生 found in the oracle bone inscriptions. While traditional commentaries have sometimes identified them as the baiguan 百官 (“the hundred officials”), Zhu Fenghan and Qiu Xigui have argued that they in fact represented the patriarchs and members of other lineages of the same clan surname. Qiu 1992: 311-320; Zhu 1990/2004: 14, 61, 279. Another interpretation has been offered by Keightley, who suggests that the relevant character 生 could also represent the written form of the word sheng 侽 and thereby refer to nephews and cousins of the ruling lineage. Keightley 1999: 49. Further evidence for a similar interpretation has been recently provided by Maria Khayutina, who demonstrates that in bronze inscriptions the term is in fact used in a closely related sense by referring to the lineage's affinal relatives of the own, first and second generation. Khayutina 2014: 24.

43 See Gassmann 2006: 306, who argues that baixing "comes closest to our expression 'population”. Although Gassmann assumes that the word min developed its new meaning at the beginning of the Han Dynasty and became a synonym of the word baixing, the passages quoted above demonstrate that this must have occurred long before the end of the Warring States Period. 
above-quoted passages universally understand the social role of the $\min$ as those being governed by the ruler and his officials and, in the case of the "Zi yi", they are even directly referred to as those "below" (xia). All of the evidence therefore argues for an interpretation of min (and baixing) in the sense of "the common people", and generally refers to the lower population strata of the territorial states. In comparison to the usage of min in Han Dynasty texts, the intriguing question remains of whether this category had reached down to the "lowest of the low" of Warring States society or whether it had already been positioned between the “officials" ( $l i$ 吏) and the “slaves” ( $n u$ 奴). ${ }^{44}$ On the basis of the quotations presented above, I am inclined to agree with such an interpretation. However, I will temporarily avoid giving a definitive answer and leave this issue to be resolved in future discussions. Nevertheless, what can be said in regard to the specific semantic framework of min is that its complementary counterpart ren apparently underwent a similar semantic change and continued to be used and in relation to a now merely vertical hierarchy. ${ }^{45}$

\section{Conclusion}

What generally can be interfered from this study is that the translation and interpretation of the word min in Zhou Period texts should be conducted with great care. As the above-quoted passages from the Zuozhuan and the Guoyu demonstrate, a usage of min similar to that of Western Zhou Period sources appears to have still existed in some texts compiled in the early Warring States Period. This may be regarded as evidence for an earlier origin of these texts, but it could also indicate that min was used simultaneously in different senses for a significant period of time. ${ }^{46}$ Further, taking into consideration that received works as the Zuozhuan and Guoyu most likely represent large compilations of

44 In legal documents of the Han Dynasty min refers to "free men" and is distinguished from “slaves” ( $(n u)$ or “officials” (li) and “convicts” (tuli 徒隸). See Lau \& Lüdtke 2012: 140, fn. 760. 45 See the accounts of Zhao 1976: 1-59, Ames \& Hall 1987: 138-156 and Song 2003: 21-40, whose studies of the meanings of min and ren in the Lunyu all place them within vertical hierarchies. However, the interpretation of Zhao Jibin, who regards min as slaves and the property of ren, is clearly incorrect. Contrary evidence can be found in a study conducted by Zhang Rongfang (Zhang 1979: 30-43). More convincing appear to be the depictions of Ames and Song, who argue that the dividing line between ren and min is based upon meritocratic principles and distinguishes between "cultivated persons" and the "uncultivated masses".

46 As linguistic studies have pointed out, semantic change is never a uniform process simultaneously conducted by all relevant speakers. Therefore, different meanings of one word can overlap significantly, giving rise to the phenomenon of polysemy. See Blank 1997: 114-116. 
different layers of texts, written, enhanced and edited over a longer period of time, it would be clearly incautious to simply project the above-derived readings upon every passage containing the word min. That is not say that the interpretation I have offered might not represent a very dominant usage of the word. However, that min could have been used in different senses in synchronous sources and was thereby of polysemous character is highly likely, as much as there is little doubt that the complementary term ren could also have possessed the meaning "human". 47 Even though this suggests that there might be even further usages of min which have not been identified yet, this does not relativize the results of this study. At any rate, it calls for a cautious reexamination of many traditionally received documents, especially since the two different meanings that I have presented above, have a profound impact on the overall worldview and intentions of many texts. As I have already argued with regard to Western Zhou sources, interpreting the term $\min$ to refer to the lower population strata of the entire Zhou Kingdom would probably mislead the reader into understanding many relevant passages as an expression of an altruistic, benevolent concern of the Kings of Zhou for the general welfare of "the common people". However, this does not necessarily reflect the actual case. Instead, it appears more likely that the Kings were concerned about upsetting the powerful patriarchs and lineages of the regional states, and provoking military uprisings that could seriously threaten the rule of the Zhou. Therefore, the "humanistic

47 In fact, there are also examples suggesting that min could have had a "hierarchy-neutral" usage in a very similar sense. One example would be the phrase sheng min 生民 ("to give birth to min"), which can be found in many received documents and appears to use min to refer to the birth of humans or the entire race of humanity itself. See e. g. a passage from the Mengzi, 2A.2, p. 216: 自有生民以來, 未有孔子也。“Since the birth of mankind there hasn't been someone like Confucius.” Or, in the Mozi, 4.16, p. 178: 夫丵泰山以趙江河, 自古之及今, 生民而來,

未嘗有也。“To jump across the Yellow river, carrying Mount Tai under one’s arm, from antiquity until today, since the birth of mankind, this hasn't happened yet!” Or, in the Guoyu 10.1, p. 337: 黃帝以姬水成, 炎帝以姜水成。成而異德, 故黃帝為姬, 炎帝為姜。二帝用師以相濟 也, 異德之故也。異姓則異德, 異德則異類。異類雖近, 男女相及, 以生民也。“The Yellow Emperor grew up at the waters of Ji, the Flame Emperor grew up at the waters of Jiang. Grown up they were of different character, thus the Yellow Emperor carried the clan surname Ji, the Flame Emperor the clan surname Jiang. Both Emperors waged war against each other because of their different character. [Having] a different clan name is due to [possessing] a different character, [possessing] a different character is due to [belonging to] a different kind. Even if different kinds are close [to each other], men and women come together to give birth to min." Unfortunately, the scarcity of such instances makes it difficult to evaluate their relation to the meaning of min discussed in this article. It is possible that these meanings are the results of semantic changes during the Warring States Period. However, it is also possible that they are remnants of an earlier usage. For more, see Schuessler 2007: 386. 
sense of anxiety" (youhuan jingshen 憂患精神) for the min that is witnessed in many texts of the Book of Documents or Book of Odes may be of a less noble character and more a result of a good deal of self-interest. Similar things can certainly also be said about anecdotes in the Zuozhuan, which often emphasize the significance of the well-being of the min. For example, the dafu Ji Liang 季梁 of the country of Sui 隋 is quoted in the Zuozhuan claiming that, "In relation to the min, they are the masters of the [ancestral] spirits. Thus the holy Kings first appeased the min and then the spirits with all [remaining] means." (fu min, shen zhi zhu ye. shi yi sheng wang xian cheng min, er hou zhi li yu shen. 夫民，神之主 也。是以聖王先成民, 而後致力於神。Zuozhuan, “Zhuan”: Huan 6.2, p.111). Reading $\min$ in the sense of its later development, one might be inclined to think of this passage as an almost categorical appeal that any government should serve "the people". However, judging by the passages from the Zuozhuan quoted above, Ji Liang's claim is probably only a warning against the belief that stable government could be achieved solely by the regular carrying out of religious sacrifices, without paying attention to one's personal ties to subjected lineages and ruling houses. With regard to the militaristic strength and danger of other inferior lineages, which is attested to countless times in the Zuozhuan through the depiction of uprisings and wars between the different ruling houses within one country, his words clearly suggest a rather pragmatic attitude. By contrast, the accounts found in the texts of the middle or late Warring States Period, as the above-quoted passages from the Mozi or Mencius, appear to be more based upon an idealistic background formed by certain moral believes.

Ironically, much of the argumentation of these later texts of the Warring States Period in favor of a more "humanistic" governmental attitude is often legitimized by quotations from earlier documents, such as the Books (Shu 書) or Odes (Shi 詩). One can therefore finally raise the rather provocative question of the extent to which such idealism may have been based on the (possibly even deliberate) misinterpretation of the word min in texts of the early Zhou Period, thus leading to the belief that the former kings had been constantly living in anxiety about the welfare of "the common people".

Acknowledgments: My thanks go to my doctoral supervisor, PD Dr. Christian Schwermann, whose seminar on the social history of the Zhou Period in 2013 initially exposed me to the issue discussed here. Without his insistence that "this word must have meant something more specific than just "the people", I would certainly have lacked the necessary motivation for this study. Furthermore, his attentive support for the papers that have resulted from my research has been essential for this article. In addition, Prof. Ralph Kauz ought to be thanked for 
including my first study to the Orientierungen. Last but not least, I would also like to express my gratitude to the anonymous reviewers of my article for their helpful suggestions and criticism, and in particular Maria Khayutina, as she later revealed herself as being one of them. It goes without saying that remaining mistakes and shortcomings in this paper remain my own responsibility.

\section{Bibliography}

\section{Excavated Sources}

Guodian. Jingmenshi Bowuguan 荊門市博物館 (1998): Guodian Chu mu zhujian 郭店楚墓竹簡. Beijing: Wenwu chubanshe 文物出版社.

JC. Zhongguoshehui Kexueyuan Kaogu Yanjiusuo 中国社会科学院考古研究所 (2007): Yin Zhou jinwen jicheng (xiuding zengbuben) 殷周金文集成（修訂增補本）. Beijing: Zhonghua shuju 中华书局.

\section{Received Sources}

Chunqiu fanlu. Su Yu 蘇輿 (1992): Chunqiu fanlu yizheng 春秋繁露義證. Beijing: Zhonghua shuju 中华书局.

Guoyu. Xu Yuangao 徐元誥 (2002): Guoyu jijie 國語集解. Beijing: Zhonghua shuju 中华书局.

Han Feizi. Wang Xianshen 王先慎 (2003[1998]): Han Feizi jijie 韓非子集解. Beijing: Zhonghua shuju 中华书局.

Liji Zhengyi. Kong Yingda 孔穎達 (1980): Liji zhengyi 禮記正義. In: Ruan Yuan 阮元: Shisanjing zhushu 十三經注疏. Beijing: Zhonghua shuju 中华书局, 1221-1696.

Lunyu. Liu Baonan 劉寶楠 (1980): Lunyu zhengyi 論語正義. Beijing: Zhonghua shuju 中华书局. Mao Shi zhengyi. Kong Yingda 孔穎達 (1980): Mao Shi zhengyi 毛詩正義. In: Ruan Yuan 阮元: Shisanjing zhushu 十三經注疏. Beijing: Zhonghua shuju 中华书局, 259-630.

Mengzi. Jiao Xun 焦循 (1987): Mengzi zhengyi 孟子正義. Beijing: Zhonghua shuju 中华书局. Mozi. Sun Yirang 孫詒讓 (2001): Mozi jiangu 墨子閒詁. Beijing: Zhonghua shuju 中华书局.

Shiben. Song Zhong 宋衷 (1957): Shiben ba zhong 世本八種. Shanghai: Shangwu yinshuguan 商务印书馆.

Zuozhuan. Yang Bojun 楊伯君 (1981): Chunqiu Zuozhuan zhu 春秋左傳注. Beijing: Zhonghua shuju 中华书局.

\section{Secondary Sources}

Ames, Roger T./Hall, David L. (1987): Thinking through Confucius. Albany: New York State Press. Blank, Andreas (1997): Prinzipien des lexikalischen Bedeutungswandels am Beispiel romanischer Sprachen. Tübingen: Max Niemeyer Verlag. 
Brooks, E. Bruce / Brooks, A. Taeko (2002): "The Nature and Historical Context of the Mencius". In: Mencius: Contexts and Interpretations. Edited by Alan K. L. Chan. Honolulu: University of Hawai'i Press, 242-281.

Crone, Thomas (2014): “Der Begriff mín 民 in Texten der Westlichen Zhōu-Dynastie (1050-771 v. Chr.)". Orientierungen 2014.1: 33-53.

Fraser, Chris / The Stanford Encyclopedia of Philosophy (Summer 2014): Mohism. http://plato.stanford.edu/archives/sum2014/entries/mohism/ (01.04.2015).

Gassmann, Robert (2006): Verwandtschaft und Gesellschaft im alten China. Begriffe, Strukturen, Prozesse. Bern et al: Peter Lang Verlag.

Hsu, Cho-yun (1965): Ancient China in Transition: An Analysis of Social Mobility, 722-222 B.C. Stanford: Stanford University Press.

Hsu, Cho-yun (1999): "The Spring and Autumn Period". In: The Cambridge History of Ancient China. Edited by Michael Loewe and Edward L. Shaughnessy. Cambridge et al: Cambridge University Press, 545-586.

Keightley, David N. (1999): “At the Beginnig: The Status of Women in Neolithic and Shang China”. Nan nü 1999.1: 1-57.

Keightley, David N. (2012): Working for His Majesty. Berkeley: Institute of East Asian Studies.

Khayutina, Maria (2014): “Marital Alliances and Affinal Relatives (sheng 侽 and hungou 婚媾) in the Society and Politics of Zhou China in the Light of Bronze Inscriptions". Early China 2014: 1-61.

Lau, Ulrich (1999): Quellenstudien zur Landvergabe und Bodenübertragung in der westlichen Zhou-Dynastie (1045? -771 v. Chr.). Nettetal: Steyler Verlag.

Lau, Ulrich / Lüdke, Michael (2012): Exemplarische Rechtsfälle vom Beginn der Han-Dynastie: Eine kommentierte Übersetzung des Zouyanshu aus Zhangjiashan/Provinz Hubei. Tokyo: ILCAA.

Lewis, Mark E. (1999): “Warring States: Political History”. In: The Cambridge History of Ancient China. Edited by Michael Loewe and Edward L. Shaughnessy. Cambridge et al: Cambridge University Press, 587-650.

Li, Feng (2006a): Landscape and Power in Early China: The Crisis and Fall of the Western Zhou, 1045-771 BC. Cambridge: Cambridge University Press.

Li Xueqin 李学勤 (2006b): “Qihou hu de niandai yu shishi” 齐侯壶的年代与史事. Zhonghua wenshi luncong 中华文史论从 2006.2: 1-6.

Li, Feng (2008): Bureaucracy and the State in Early China: Governing the Western Zhou. Cambridge: Cambridge University Press.

Matsui Yoshinori 松井嘉徳 (2001): “Shū no kokusei: Hōkensei to kansei o chūshin ni toshite" 周の国制: 封建制と官制を中心にとして.In: In Shū Shin sKan jidaishi no kihon mondai 殷周秦漢時代史の基本問題. Edited by Matsumaru Michio 松丸道雄. Tokyo: Kyūko shoin 汲古書院, 89-112.

Pines, Yuri (2009): Envisioning Eternal Empire: Chinese Political Thought of the Warring States Era. Honolulu: University of Hawai'i Press.

Qiu Xigui 装锡圭 (1992): Gudai wenshi yanjiu xintan 古代文史研究新探. Nanjing: Jiangsu guji chubanshe 江苏古籍出版社.

Schwermann, Christian (2011): "Dummheit" in altchinesischen Texten. Eine Begriffsgeschichte. Wiesbaden: Harrassowitz.

Song Yongpei 宋永培 (2003): “Lunyu min, ren de shiji suo zhi yu ciyi tedian” 《论语》“民”、“人” 的实际所指与词意特点. Guji zhengli yanjiu xuekan 古籍整理研究学刊 2003.6: 21-40. 
Van Auken, Newell A. (2011): "Who is a rén 人? The Use of rén in Spring and Autumn Records and Its Interpretation by the Zuǒ, Gōngyáng and Gǔliáng Commentaries”. Journal of the American Oriental Society 131.4: 555-590.

Von Falkenhausen, Lothar (2006): Chinese Society in the Age of Confucius (1000-250 BC): The Archaelogical Evidence. Los Angeles: The University of California.

Yoshimoto Michimasa 吉本道雅 (2001), “Kokusei shi” 国制史. In: In Shū Shin Kan jidaishi no kihon mondai 殷周秦漢時代史の基本問題. Edited by Matsumaru Michio 松丸道雄. Tokyo: Kyūko Shoin 汲古書院, 63-88.

Zhang Rongfang 张荣芳 (1979): “Liang Zhou de min he meng feinulishuo: liang Zhou shengchanzhe shenfen yanjiu zhi yi” 两周的民和讯非奴隶说一一两周生产者身份研究之一. Zhongshan Daxue xuebao 中山大学学报 1979.3: 30-43.

Zhao Jibin 赵纪涁 (1976): Lunyu xintan 论语新探. Beijing: Renmin chubanshe 人民出版社.

Zhu Fenghan 朱风翰 (2004 [1990]): Shang Zhou jiazu xingtai yanjiu 商周家族形态研究, Tianjin: Tianjin guji chubanshe 天津古籍出版社.

\section{Dictionaries}

Luo Zhufeng 罗竹风 (ed.) (1986): Hanyu dacidian 汉语大词典. Shanghai: Hanyu dacidian chubanshe 汉语大词典出版社.

Schuessler, Axel (2007): ABC Etymological Dictionary of Old Chinese. Honolulu: University of Haiwai'i Press. 